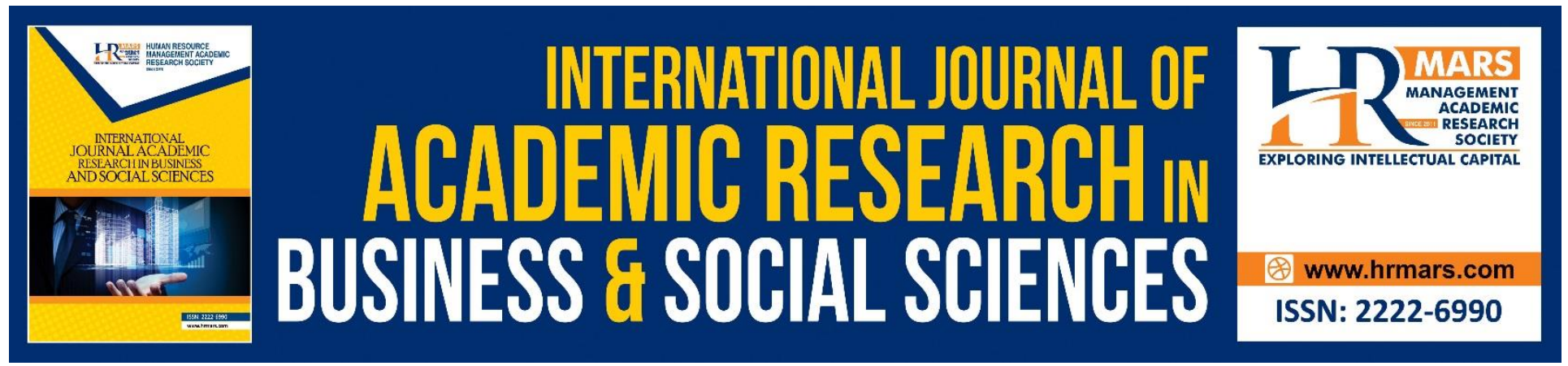

\title{
Relationship between Human Resource Practices and Talent Retention among Professional and Management Staff of a Public University in Malaysia
}

Siti Rozana Supian, Ismi Arif Ismail, Fatimah Sidi and Zoharah Omar

To Link this Article: http://dx.doi.org/10.6007/IJARBSS/v8-i7/4423

DOI: $10.6007 /$ IJARBSS/v8-i7/4423

Received: 08 June 2018, Revised: 26 June 2018, Accepted: 29 June 2018

Published Online: 18 July 2018

In-Text Citation: (Supian, Ismail, Sidi, \& Omar, 2018)

To Cite this Article: Supian, S. R., Ismail, I. A., Sidi, F., \& Omar, Z. (2018). Relationship between Human Resource Practices and Talent Retention among Professional and Management Staff of a Public University in Malaysia. International Journal of Academic Research in Business and Social Sciences, 8(7), 834-862.

Copyright: (C) 2018 The Author(s)

Published by Human Resource Management Academic Research Society (www.hrmars.com)

This article is published under the Creative Commons Attribution (CC BY 4.0) license. Anyone may reproduce, distribute, translate and create derivative works of this article (for both commercial and non-commercial purposes), subject to full attribution to the original publication and authors. The full terms of this license may be seen

at: $\underline{\text { http://creativecommons.org/licences/by/4.0/legalcode }}$

Vol. 8, No. 7, July 2018, Pg. 834 - 862

http://hrmars.com/index.php/pages/detail/IJARBSS

JOURNAL HOMEPAGE

Full Terms \& Conditions of access and use can be found at

http://hrmars.com/index.php/pages/detail/publication-ethics 


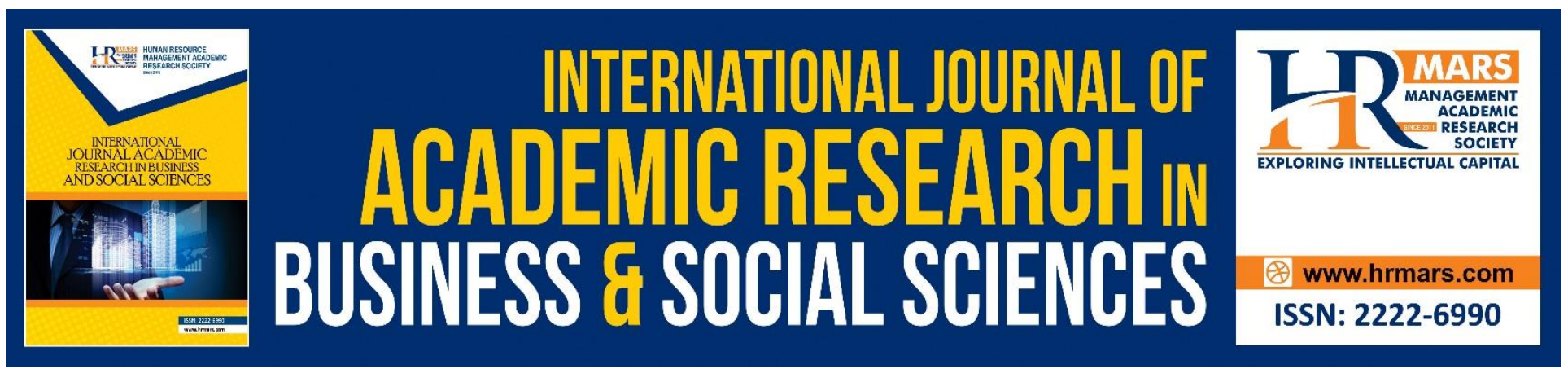

\title{
Relationship between Human Resource Practices and Talent Retention among Professional and Management Staff of a Public University in Malaysia
}

\author{
Siti Rozana Supian, Ismi Arif Ismail, Fatimah Sidi and Zoharah Omar \\ Faculty of Educational Studies, Universiti Putra Malaysia, 43400 UPM Serdang, Selangor, Malaysia \\ Faculty of Computer Science and Information Technology, Universiti Putra Malaysia, 43400 UPM \\ Serdang, Selangor, Malaysia
}

\begin{abstract}
The main objective of this study is to examine the relationship between human resource practices and talent retention and at the same time determine the dominant factor that contributes to talent retention among the professional and management staff in Uni A. Descriptive and correlational methods were used as the study design and a total of 381 of professional and management staffs was selected using non-proportionate simple random sampling method. Self-administered questionnaires were distributed and $282(74 \%)$ responses were collected. Finding of study indicates that human resource practice that consists of eight variables correlates significantly with retention. Organizational work environment was found to have the strongest correlation with retention followed by organizational leadership, and person-organization fit, and teamwork. Second, the result also confirms that there is a significant influence of human resource practice on talent retention. Apparently, work environment was found to be the dominant human resource practice in retaining talent in Uni A and it also exposes that organizational commitment model was found to be more effective to measure the influence of HRP on retention as compared to intent to stay model. Thus, from the study it can be concluded that work environment is the key human resource practices in retaining talent in Uni A followed by organizational leadership and person-organization fit. Ignoring this relationship will be a risk to talent retention in Uni A and affecting university's function and performance. It is recommended that the university to invest money and effort as to implement a structured retention management strategy in order to retain talent focusing on work environment, leadership development and person-organization fit.
\end{abstract}

Keywords: Human Resource Practices, Talent Retention, Public University in Malaysia

\section{Introduction}

Talent Retention in Malaysia Public University

The increasing competition and liberalization of education in Malaysia have made talent retention as a more critical agenda in Malaysia Public University than ever. As Malaysian higher education 
embarked on the liberalization, democratization and privatization in middle of 1990s, it marked the beginning of the agenda of attracting and retaining talent among the higher education institutions and universities. The establishment of new public university; from five (5) universities to twenty (20) and currently as more than 500 private education institutions established, causing rapid mobility between these institutions of higher learning involving the academicians as well as the administrators. Malaysian Medical Association reported that mobility among the clinical academics from the public universities are the highest for the past few years to work at private institutions and hospitals (Chin, 2014). Shortages of the clinical academics require Malaysia government and universities to plan measures in order to curb the brain drain among the public universities. Malaysia's aspiration to emerge as a regional education hub would require the standard quality assurance of teaching and learning while exerting greater accountability to students, parents and stakeholders (Abd. Aziz \& Abdullah, 2014). Therefore, this expectation towards producing employable graduates would demand for the retention of the best talent in the universities.

It is becoming even more imperative for Malaysia public universities to manage and retain talents with the launching of Malaysia's New Economic Model (NEM) in 2010 as Malaysia gears towards producing knowledge workers and attaining a high income nation by 2020 (Arokiasamy, Ismail, Ahmad, \& Othman, 2011; Darling Hammond, 2010). However, the purported alarming trend of migration of Malaysian professionals abroad at an estimated diaspora of 1.5 million people posed as one of the Malaysia's biggest challenge in its efforts to achieve the developed or high income nation (Puteh, Nor, \& Zulkifli, 2012). As part of the efforts to address the issue of Malaysian talents from going overseas, Talent Corporation Malaysia is established aiming at attracting Malaysian professionals abroad to contribute to the country's development by returning to Malaysia.

In addition, the research university (RU) recognition introduced in 2006 posed the importance of retaining talent in the universities. The first RU status was awarded to four Malaysia public universities namely Universiti Sains Malaysia (USM), Universiti Putra Malaysia (UPM), Universiti Kebangsaan Malaysia (UKM) and Universiti Malaya (UM). The RU aiming at pursuing the national agenda to transform into a competitive economy, the RU is different from other universities by its capability of conducting research and development, innovation and commercialization that definitely would require a pool of professionals, knowledgeable and highly skilled workers in the public universities (Noraani \& Wee Yu Ghee, 2013).

To date, Malaysia public university's management become more dynamic and complex which requires the university to invest to attract the best talent and retain them as long as possible in the university. The roles of professional and management staff in a university are interrelated to attain University Good Governance Index (UGGI) in terms of institutional, financial, human resource and academic governance. UGGI has been accepted as a measure of the readiness of universities to be granted autonomy (Hashim, 2010). By attaining the UGGI, the government will grant the university with a greater autonomy. In addition to UGGI, participating to the university world ranking also reshaping the university and its talent to become more competitive while promoting quality and excellence in higher education (Hazelkorn, 2013).

Therefore, retaining talent in Malaysia public university is crucial towards transforming Malaysia into a knowledge-based economy nation and finally supporting the Malaysian New Economic Model. 
INTERNATIONAL JOURNAL OF ACADEMIC RESEARCH IN BUSINESS AND SOCIAL SCIENCES Vol. 8, No. 7, July 2018, E-ISSN: 2222-6990 @ 2018 HRMARS

Moreover, the world class university ranking exercise including the benchmarking strategies with other leading universities to enhance university competitiveness contribute to the importance of talent retention management in Malaysia higher education system.

\section{Statement of Problem}

Talent is an important resource for the organizational success and sustainability (Shaw, 2011; Iles, Chuai, \& Preece, 2010; Davies \& Davies, 2010; Huselid, 1995; Wright, McMahan, \& McWilliams, 1994) and the need to retain talent is recognised by most organisation worldwide (Mendez \& Stander, 2011). However, most of previous studies had given emphasis more on the issues of turnover rather than the retention of talent (Park \& Shaw, 2013; Hausknecht \& Trevor, 2011; Batt \& Colvin, 2011; Siebert \& Zubanov, 2009). Previous studies in turnover mostly examined the effects of human resource practices on quit rates and discharge rates at the individual and organizational levels. In contrast, talent retention studies examined the factors that influence talents' intention to stay in the organization while the talents still employed in the organization. In addition, much of the research has been dedicated to the best practices in talent retention in the profit making entities such as the hotels, medical and multinational companies (Mohan \& Russell, 2010; Siebert \& Zubanov, 2009; Grobler \& Diedericks, 2009; Hughes \& Rog, 2008). It is noted that little study has been done to address the impact and relationship between human resource practices and talent retention particularly in the public higher education institution or university in Malaysia. Few studies measure the relationship between benefit i.e. leave, loan and retirement plan and also the impact of human resource management such as employee training, appraisal system, employee compensation and empowerment on retention (Ng Chee Hong, Lam, Kumar, Ramendran \& Kadiresan, 2012). Besides those human resource practices studied earlier, there are many other human resource practices to be considered on their impact on talent retention. Hence, this study is carried out to assess and identify the relationship as well as the influence of human resource practices on retaining talent in a public university in Malaysia.

\section{Review of Literature}

\section{Definition of Human Resource Practices}

Individuals who make up the workforce of an organization or business is called as human resources. Human resources is also known as human capital or sometimes called as manpower, talent, labour, or simply people. Previous researchers highlighted that people management is more complex and cumbersome than managing machine or money (Lado \& Wilson, 1994; Barney, 1991) and organizations which manage their human resources well will have competitive advantage over their competitors (Wright et al., 1994).

In order to achieve the organizational goals, it requires a sound human resource practices. This refers to human resource related activities directed at managing the pool of human resources and ensuring that the resources are employed towards the fulfilment of organizational goals (Jackson \& Schuler, 1996). HRD practices involves a distinctive approach in recruiting highly committed and skilled workforce, activities to improve staff organizational behaviour such as commitment, competency and performance (Koch \& McGrath, 1996). 
INTERNATIONAL JOURNAL OF ACADEMIC RESEARCH IN BUSINESS AND SOCIAL SCIENCES Vol. 8, No. 7, July 2018, E-ISSN: 2222-6990 @ 2018 HRMARS

\section{Human Resource Practices Influencing Talent Retention}

In this study, it focuses on eight types of human resource practices, namely person organization fit, remuneration and recognition, training and career development, challenging assignment opportunity, leadership, teamwork, communication and work environment as the variables in which their impact on retention of the people or talent in Uni $A$ is examined.

Human resource practices make up as part of the strategic initiatives in managing and retaining talent (Arthur, 1994; Huselid, 1995; Koch \& McGrath, 1996). Human resource practices designated to enable achieving success through its people (Armstrong, 2009; Becker \& Gerhart, 1996). Human resource practices such as training and career development, teamwork, compensation, performance appraisal helps improve organizations' performance (Lee \& Lee, 2007). It was suggested that human resource practices improved organizational outcomes through shaping employees behaviour and attitude (Kehoe \& Wright, 2010). Moreover, human resource practices are related to an increase of employees' commitment to an organization (Arthur, 1994). Organizational commitment among employees would make them involved in the organization, and work hard to accomplish organization's goal and finally leads to lower turnover and high in productivity (Youndt, 2000). In general, human resource practices includes functions such as job analysis, design, recruitment/selection, training and development, performance management, remunerations/benefits, as well as labour and employee relations (De Cieri \& Kramar, 2008; Delery \& Doty, 1996). Through the policies enacted, methods and strategies used to attract and retain the right talent will develop a sustainable competitive advantage organization (Holland et al., 2007).

In addition to the above, in this study, the eight types of human resource practices are also considered as bundles of human resource practices that consists of two factors. First is the human resource factors that resides internally within the human resource such as their fit on organization values, satisfaction on remuneration and recognition, level of training and development, and the amount of job assignments and challenging opportunities received. The second factor is the organizational factors that revolve externally within the human resource namely organizational leadership, communication, teamwork relationship and work environment.

\section{Human Resource Factors}

Human resource factors that affect retention, job satisfaction and organization performance are as follows:

\section{Person-Organizational Fit}

Person-organization fit emphasizes on matching people and job in terms of qualifications based on knowledge, skill, or ability, and overlooking other personal characteristics of applicants that might be more suitable for the assessment of "fit" (Edwards, 1991). Person-organization fit is considered in the context of personnel selection and can be based on the congruity between personal and organization beliefs (Netmeyer, Boles, McKee, \& McMurrian, 1997). In addition, person-organization fit in term of work values and honesty will increase in work outcome, and retention (Swaney, Alllen, Casillas, Hanson, \& Robbins, 2012; Greguras \& Diefendorff, 2009). 
INTERNATIONAL JOURNAL OF ACADEMIC RESEARCH IN BUSINESS AND SOCIAL SCIENCES Vol. 8, No. 7, July 2018, E-ISSN: 2222-6990 @ 2018 HRMARS

\section{Remuneration and Recognition}

A fair wage implied agreements between employees and employers, the underlying assumption being that money can influence behavior (Hansen, Smith, \& Hansen, 2002; Parker \& Wright, 2000). Organization provide pay packages superior to the market to attract and to retain talent. Innovative compensation such as profit sharing and group-based incentive pay were introduced by organization using high performance work practices (Bassi \& Van Buren, 1999). Though pays continue to be important in determining motivation to perform, other non-monetary benefits known as rewards or recognition play a significant role in compensation satisfaction. A sense of accomplishment is recognized as important and a strong motivator. Employees tend to stay with the organization when they feel their capabilities, effort, and performance contributions are recognized and appreciated (Davies, 2001). Rewards-retention link study provided support to the belief that a broad and wellimplemented rewards and recognition program assists in talent retention management (Mercer, 2003). In addition, a study on job satisfaction among doctors showed that recognition for high work quality, teamwork and promotion opportunities have direct effect on retention and satisfaction while pays and better incentive package sometimes were not necessarily be the dominant factors for retention (Nazir, Khan, Hussain Shah, \& Zaman, 2013).

\section{Training and Career Development}

Training is considered a form of human capital investment made by an organization to enhance employee job skills and knowledge, apply and share with others (Noe, 1999). Training is needed to close the gap or deficiencies of employees performances including improving the technological knowhow, communication, or problem solving; while career development mean an effort made to provide employees with the abilities that the organization will need in the future (Capelli, 1995). Training and career development of employees has been recognized as an important part of human resource management as they increase employee commitment (Oakland \& Oakland, 2001). Thus, training and career development can serve to increase staff intention to stay in an organization (Frazis, Gittleman, Horrigan, \& Joyce, 1998). Training and career development activities that encourage innovative, creativity and providing opportunities for personal career development will contribute to retention (Chung \& Jing, 2009; Kwenin, 2013; Sinha \& Sinha, 2012).

\section{Challenging Employment Assignment and Opportunities}

Employees need to be stimulated with creative challenges or they will go where the excitement is, be it in another department, industry or company. Allowing a challenging assignment or cross department projects with well-defined performance measures will encourage employees to achieve their personal objectives (Furnham, 2002) while mastering new skills will keep employees to be creative and nurturing them with a broad of experience (Ferguson, 1990). Organization that failed in providing challenging assignment and opportunities, freedom to be creative, opportunities to develop new skills among the employees, will lower organizational commitment, and increase their greater intention to leave the organization (Phillips, 1997). Thus, providing opportunities to learn new things, challenging work assignments and work autonomously on their work assignment are the human resource factors that contributed to lower turnover and increase talent retention (Carette, Anseel, \& Lievens, 2012; Preenen, De Pater, Van Vianen, and Keijzer, 2011; Fatima, 2011).

\section{Organizational Factors}

Few organizational factors that affects retention are as follows: 
INTERNATIONAL JOURNAL OF ACADEMIC RESEARCH IN BUSINESS AND SOCIAL SCIENCES

Vol. 8, No. 7, July 2018, E-ISSN: 2222-6990 @ 2018 HRMARS

\section{Organizational Leadership}

Leadership is defined as the non-coercive influence behavior of a person when directing and coordinating an activities of a group of people towards the accomplishment of a shared goal and organizational effectiveness (Hoffman, Strang, Kuhnet, Campbell, Kennedy, \& LoPilato, 2013; Byrman, 1992). Leadership consists of four tasks: providing direction, assuring alignment, building commitment, and facing adaptive challenges (Leimbach, 2006; Risher \& Stopper, 2002).

\section{Teamwork Relationship}

Employees stay when they have strong relationship with their colleagues (Clarke, 2001). Organizations that encourage team work, cross departmental project with peers, and opportunities for social interaction which enhance bonding among members and consequently, increase organizational commitment (Abdullah, et al., 2012; Kalisch, Lee, \& Rochman, 2010; Meyer \& Allen, 1997).

\section{Communication}

Communication emerged as an essential process in people management. Communication can be in the form of a well-informed of organization's goals, vision, strategies, policies, rules and regulations (Gilley, Gilley, \& McMillan, 2009). A horizontal and vertical communication of facts, and information will provide common understanding across all level and thus develop trust between employees and leaders (Muhammad, Ur Rehman, Safwan, \& Asad, 2012; Carter, Ulrich, \& Goldsmiths, 2005; Hart, Miller, \& Johnson, 2003). An effort towards providing a clear data communication structured towards responding to staffs' complaints and ideas will contribute to enhance job satisfaction and staffs' intention to stay (Muhammad et al., 2012; Sh. Kandelousi \& Kim Seong, 2011; Gilley, Gilley, \& McMillan, 2009; Carter, Ulrich, \& Goldsmiths, 2005)

\section{Working Environment}

Personal and family lives did affect employees' decision either to leave or to stay at one's organization. Organizations that help employees to manage their work and personal life issues such as life stage needs, health, location, family, dual-career and other personal needs will win employees to stay longer (Perry-Smith \& Blum, 2000). Therefore, many organizations have successfully created an employee-friendly environment by integrating specialized work arrangements such as flexible hours, telecommuting, and family-leave assistance to support employees to experience a more conducive work environment and to practice work life balance. The importance of work life family balance, harmonious work environment as well as a safe and good physical work condition would contribute to job satisfaction among employees, increased retention and high quality organization performance (Vijaimadhavan \& Raju M.Com, 2013; Akintayo, 2012; Chandrasekar, 2011; Beham \& Drobnic, 2010).

\section{Methodology}

\section{Research Design and Location of the Study}

In pursuing this study, a quantitative method using a descriptive and correlational research was chosen to investigate the influence of human resource practices on the talent retention of the professional and management staff in a public university in Malaysia. This study was conducted in 
INTERNATIONAL JOURNAL OF ACADEMIC RESEARCH IN BUSINESS AND SOCIAL SCIENCES Vol. 8, No. 7, July 2018, E-ISSN: 2222-6990 @ 2018 HRMARS

one of the research universities in Malaysia (Uni A). Uni A is also known as one of the premier public universities in Malaysia.

\section{Population and Sampling}

The population of the study is among the professional and management staff in all faculties and offices in Uni A consisting of the academicians and administrators. The current statistics shows that there are 1223 academicians and 960 administrators which totalled up to 2183 staffs in Uni A. In order to obtain an accurate estimate of the relationship between variables, at least one hundred participants are required from a defined population. The sample size calculated using formula $50+$ $8 \mathrm{~m}(\mathrm{~m}=$ number of independent variable) by Tabachnick and Fidell (2007) showed a sample size of 114. However in this study, the sample size was set to 381 respondents in order to increase responses and to ensure the representativeness of population in the study. There are 16 faculties in Uni $A$ where the academicians resided while the administrators were placed across faculties, offices, centres, and institutes. A non-proportionate random sampling technique was selected in this study whereby 13 academicians selected using random number generator from each 16 faculties (total of 208 academicians) while the balance of 173 were selected from the administrator list

\section{The Instrument}

A research instrument in the form of a structured questionnaire was adopted in this study. It was used due to its efficient data collection mechanism. The instrument (questionnaire) was adopted based on previous reliable questionnaire which had been used to measure the perception of human resource practices influences on talent retention. The items in the instrument of this study was written in English and translated to Malay language and checked by a Malay language expert. Finally, to ensure and determine the content validity, the questionnaire was certified and validated by the researcher's Supervisory Committee members. 
INTERNATIONAL JOURNAL OF ACADEMIC RESEARCH IN BUSINESS AND SOCIAL SCIENCES Vol. 8, No. 7, July 2018, E-ISSN: 2222-6990 @ 2018 HRMARS

Table 3.1: Questionnaire Items

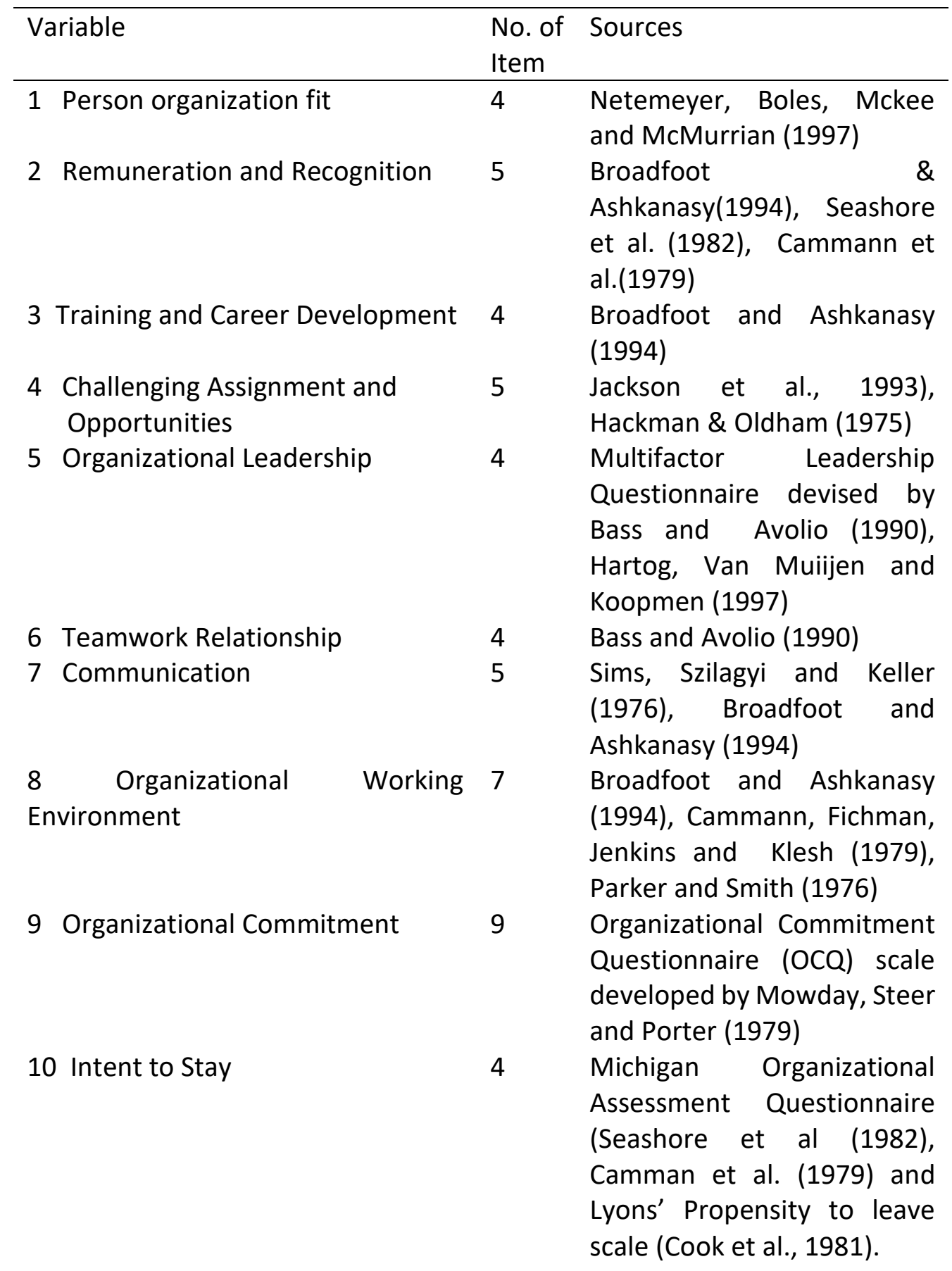

11 Demographic Total 4 55

There were 55 items in the instrument including four questions which were used to obtain demographic information namely age, gender, job placement and occupation. All items were scored 
INTERNATIONAL JOURNAL OF ACADEMIC RESEARCH IN BUSINESS AND SOCIAL SCIENCES

Vol. 8, No. 7, July 2018, E-ISSN: 2222-6990 @ 2018 HRMARS

using Likert-Type Scale i.e. a seven point scale ranging from (1) strongly disagree to (7) strongly agree (Vagias, 2006) and tested its level of significance at targeted range of $<0.01-<0.05$. Each variable was assessed using a minimum of four items and to a maximum of 9 items.

\section{Measures of Reliability}

In the pilot study, organizational fit scales, item fit 2 "values with regards to fairness" was deleted for the purpose of increasing reliability. Furthermore, the corrected item - total correlation is too low ($0.354)$. Thus reliability increased from 0.435 to 0.898 . For the organizational commitment scales, item Oc2 "working for a different organization" was deleted due to the corrected item - total correlation is too low (-0.026). Thus, reliability increased from 0.794 to 0.840 . For the intent to stay scales, item its3 "plan to stay in this job for at least two or three years" was deleted because the corrected item - total correlation is too low (0.124). Therefore, the reliability increased from 0.585 to 0.716 . The result shows that the reliability of the item selected for this study is within range $0.716-0.98$ alpha cronbach's after three items were dropped from the instrument. The dropped items involved negative and repetitive scale and by deleting them does not affect the instrument as a whole.

Table 3.2: Instrument Reliability Coefficient

\begin{tabular}{|c|c|c|c|c|c|}
\hline \multirow[t]{3}{*}{$N$} & \multirow[t]{3}{*}{ Variable } & \multicolumn{4}{|c|}{ Cronbach's Alpha Value } \\
\hline & & \multicolumn{2}{|c|}{$\begin{array}{l}\text { Pilot } \quad \text { Study } \\
(n=22)\end{array}$} & \multirow{2}{*}{$\begin{array}{l}\text { Actual } \\
(n=282) \\
\text { Item }\end{array}$} & \multirow{2}{*}{$\begin{array}{l}\text { Study } \\
\text { Alpha }\end{array}$} \\
\hline & & Item & Alpha & & \\
\hline 1 & $\begin{array}{l}\text { Person organization fit } \\
\text { (Fit) }\end{array}$ & 4 & .435 & 3 & .898 \\
\hline 2 & $\begin{array}{ll}\text { Remuneration } & \text { and } \\
\text { Recognition (REM) } & \end{array}$ & 5 & .877 & 5 & .804 \\
\hline 3 & $\begin{array}{l}\text { Training and Career } \\
\text { Development }(T C D)\end{array}$ & 4 & .878 & 4 & .887 \\
\hline 4 & $\begin{array}{l}\text { Challenging Assignment } \\
\text { and Opportunities (CAO) }\end{array}$ & 5 & .849 & 5 & .794 \\
\hline 5 & $\begin{array}{l}\text { Organizational } \\
\text { Leadership (LDR) }\end{array}$ & 4 & .982 & 4 & .948 \\
\hline 6 & $\begin{array}{l}\text { Teamwork Relationship } \\
\text { (TEAM) }\end{array}$ & 4 & .817 & 4 & .823 \\
\hline 7 & Communication (COMM) & 5 & .891 & 5 & .923 \\
\hline 8 & $\begin{array}{l}\text { Organizational Working } \\
\text { Environment (WE) }\end{array}$ & 7 & .919 & 7 & .904 \\
\hline 9 & $\begin{array}{l}\text { Organizational } \\
\text { Commitment (OC) }\end{array}$ & 9 & .794 & 8 & .840 \\
\hline 10 & Intent to Stay (Its) & 4 & .585 & 3 & .716 \\
\hline
\end{tabular}

\section{Data Collection}

A self-administered structured questionnaire in the form of electronic online survey was developed and distributed through Uni A internal mail services and sample's official email. The online survey 
INTERNATIONAL JOURNAL OF ACADEMIC RESEARCH IN BUSINESS AND SOCIAL SCIENCES

Vol. 8, No. 7, July 2018, E-ISSN: 2222-6990 @ 2018 HRMARS

was created using the free services provided by Google Docs application dated on 12 th. December 2011 and the url address to access the questionnaire was https://docs.google.com/spreadsheet/gform?key=0AizHnNOfG5EdEtNQ09NNN1puZGc1dHNUc0Jx OUE\#invite. The online questionnaire collected data and automatically filled it in a spreadsheet that can easily work on any data processing methods. For this study, the replied form were accessed from https://docs.google.com/spreadsheet/ccc?key=0AizHnNOfG5EdEtNQ09hemNNN1puZGc1dHNUc0Jx OUE. The respondents have the freedom to fill the questionnaire either through online or hardcopy by printing the online form and submitted the form to the researcher.

A cover letter signed by Uni A's Registrar requesting participation, and guaranteed confidentiality has been prepared and distributed with the questionnaire. The entire data collection phase took three months to be completed including the follow up procedure has been done by the researcher to reduce the number of missing values and collecting additional data. First, the questionnaire has been distributed within a month. After one month of the expiry of the dateline and due to less than expected reply received, the first reminder were sent by telephone call and email. Finally, data collection with a total of 282 respondents consisting of 182 online responses and 100 hardcopy returned questionnaires.

\section{Data Analysis}

In analysing the data collected from the questionnaire, the Statistical Packages for Social Sciences (SPSS) version 19.0 Window was used to generate the results of the survey.

\section{Results}

The demographic profile of the respondents was presented according to gender, age, job placement and occupation including frequency distribution and percentage of respondents. Table 4.1 shows that $(n=282)$ employees in Uni A participated in this study. Out of 282 employees participated in this study, 133 (47\%) were male employees and 149 (53\%) were female.

In terms of age of the respondents, the data showed that 95 respondents (34\%) were between ages 30-39 years old. It was followed by the age group between 40-49 years old, with 86 respondents (31\%). The third place was age group between $50-65$ years with 68 respondents (24\%). Finally, the last age group was between 20-29 years old, consisting of 31 respondents (11\%) in this age group. The results indicated the majority of the respondents or $64.3 \%$ fall under the productive age of an employment period which is between 30-39 years old and 40- 49 years old ( (Skirbekk, 2003). This posited the fact that the professional and management staff in Uni A is relatively young (34 years old and less).

With regard to job placement, the respondents were divided into six (6) categories. It indicates that most of the respondents were from the faculty members of which 144 (51\%) respondents of the study. It was followed by 40 (14\%) respondents who came from the Centres while, 35 (13\%) respondents were from the Institutes. The rest of respondents i.e 30 (11\%) from Divisions and 30 $(11 \%)$ respondents from the Offices as well as $3(1 \%)$ respondents came from the various Schools of Uni A. These result show majority of the respondent were the academicians and attached to specific faculties. While the administrators placement are scattered at the centres, institute, offices and 
INTERNATIONAL JOURNAL OF ACADEMIC RESEARCH IN BUSINESS AND SOCIAL SCIENCES Vol. 8, No. 7, July 2018, E-ISSN: 2222-6990 @ 2018 HRMARS

divisions; the technical officers such as the IT, agriculture, librarian, and financial officer are located at their specific offices and division.

By occupation, Table 4.1 shows that only eleven respondents did not state their occupation. Hence, there were 282 valid cases in the statistics out of 320 respondents. It indicates that most of the respondents were the academicians which is due to the nature of the university is designated for teaching, learning, and research. There are 136 (48\%) respondents who were academicians. The rest of respondents include 49 (17\%) administrators, 20 (7\%) research officers, 19 (7\%) librarians, 15 (5\%) others, 11 (4\%) agriculture officers, $9(3 \%)$ science officers, 7 (3\%) system analysts, medical officers $7(3 \%)$, financial officers $6(2 \%)$ and finally, only $3(1 \%)$ respondents were engineers.

\section{Relationship between Human Resource Practices and Talent Retention of Professional and Management Staff in Uni A}

Correlation analysis was conducted to address the third research objective of the study which is to identify the relationship between human resource practices and talent retention of the professional and management staff in Uni A. The relationship between human resource practices and talent retention was conducted using the Pearson product-moment correlation coefficients. Preliminary analyses were conducted to ensure no violation of the assumptions of normality and linearity.

Based on the collinearity diagnostics, none of the model dimensions had condition index equal to or above the threshold value of 30.0. None of the tolerance value smaller than 0.10 and VIF statistics are less than 10.0. This indicated that that there is no serious multicollinearity problem among the predictor variables of the estimated model.

\section{Relationship between Human Resource Practices and Talent Retention of Professional and Management Staff in Uni A}

\section{Intent To Stay}

As depicted in Table 4.14, it shows that all variables correlate significantly with intent to stay. The strongest linear relationship was found to exist between intent to stay and organizational working environment $(r=0.53, p=0.01)$. The correlation coefficient of .53 shows a positive direction with a moderate strength. The second highest correlation was found between the intent to stay and organizational leadership ( $r=0.45, p=0.01)$. The correlation coefficient of .45 shows a positive linear relationship direction and the strength was moderate. The third highest correlation was between intent to stay and teamwork $(r=0.43, p=0.01)$ with a positive direction and a moderate strength too. In addition, communication indicated a significant relationship ( $r=0.42, p=0.01)$ including remuneration and recognition $(r=0.41, p=0.01)$ which showed a positive direction and a moderate strength. Finally, there was a significant relationship between intent to stay and organizational fit $(r$ $=0.38, p=0.01)$, training and career development $(r=0.36, p=0.01)$ and challenging employment assignments $(r=0.36, p=0.01)$ though it showed a positive direction but the strength was small. 
INTERNATIONAL JOURNAL OF ACADEMIC RESEARCH IN BUSINESS AND SOCIAL SCIENCES Vol. 8, No. 7, July 2018, E-ISSN: 2222-6990 @ 2018 HRMARS

Table 4.14: Correlation between HRP Variables and Intent to Stay ( $N=282)$

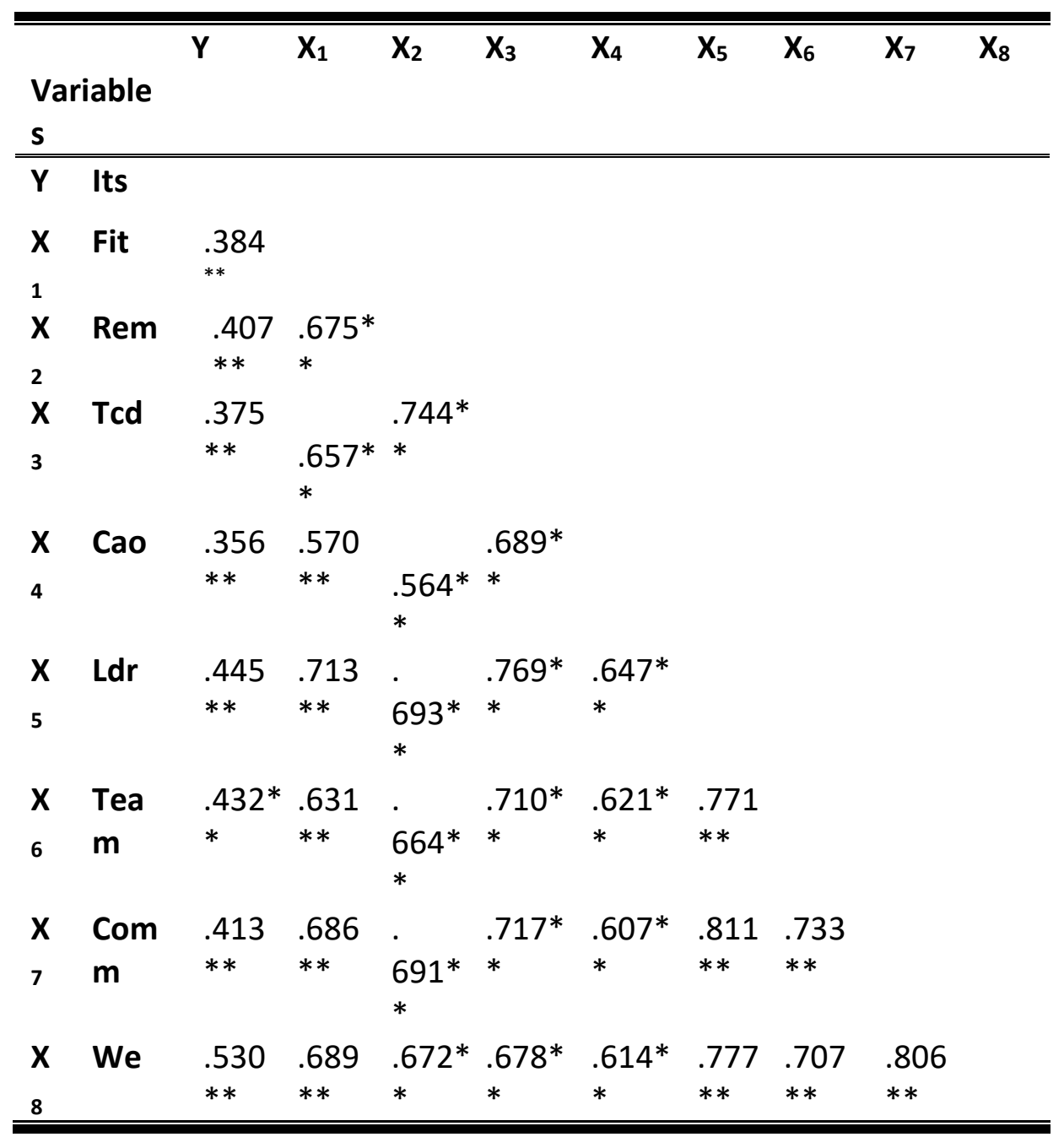

These findings highlighted that all eight variables of human resource practices in Uni $A$ have a significant relationship with intent to stay. In Uni A, it shows that organizational factors variables are having the highest significant relationship with intent to stay where organizational work environment scores the highest, followed by organizational leadership, teamwork and communication. Only remuneration and recognition show a significant relationship with intent to stay that comes from the human resource factors variables whereby three variables namely person organization fit, training and career development and challenging assignment and opportunity correlate significantly with intent to stay but with small strength.

The significant relationship between organizational work environment and intent to stay in Uni $A$ is relevant with previous research in U.S. firms where personal and family life such as health, dual career and other personal needs will convince employees to stay longer (Perry-Smith \& Blum, 2000). It is also relevant with previous study in India and Nigeria that harmonious workplace, a good physical work condition and safety promotes talent intent to stay and contributed to retention and high organizational performance (Vijaimadhavan \& Raju M. Com, 2013; Akintayo, 2012; Chandrasekar, 
INTERNATIONAL JOURNAL OF ACADEMIC RESEARCH IN BUSINESS AND SOCIAL SCIENCES Vol. 8, No. 7, July 2018, E-ISSN: 2222-6990 @ 2018 HRMARS

2011). In addition, these findings also confirm previous study in German service sector workers that highlighted the importance of work family balance (Beham \& Drobnic, 2010).

The second highest variable correlates with intent to stay is organizational leadership which states the important role of leadership to retain talent in Uni A. This finding is relevant with previous study among managers in U.S. which highlighted that effective leader and leadership practices that support high performing employee will contribute to high retention among talents (Hoffman et al., 2013). This study also confirms earlier research that leadership that provides direction will enhance retention (Leimbach, 2006), and increase job satisfaction and commitment (Aimo-Metcalfe \& AlbanMetcalfe, 2001; Podsakoff, MacKenzie \& Bommer,1996).

The third highest variable correlates with intent to stay is teamwork relationship. In Uni A, teamwork is among the important HRP in retaining talent. This is similar with previous study among employees in hotel industry in Klang Valley, Malaysia that highlighted how teamwork among colleague that maintain high standard performance are crucial in retaining talent (Abdullah et al., 2012). Finding of this study is also relevant with previous study among nurses in U.S. hospitals which indicated that cross department teamwork and members that have clear idea of group's goal will enhance retention (Kalisch, Lee, \& Rochman, 2010).

Finally, the fourth highest variable that correlates with intent to stay is communication. This finding shows similar result with previous study among public and private sector in Pakistan that effective communication affected talents' motivation and act as the vital source of their affiliation with organization and retention (Muhammad et al., 2012). It is also relevant with previous study that a well-informed matters related to talent is crucial for retention (Gilley, Gilley, \& McMillan, 2009). A study among U.S. working professionals confirmed that horizontal and vertical communication across all level played an important factor to employees' intent to stay (Carter, Ulrich, \& Goldsmith, 2005). However, the other HRP variables, namely person organization fit, remuneration and recognition, training and career development and challenging assignment and opportunities should also be considered important in leading talent to stay in Uni A.

\section{Organizational Commitment}

As depicted in Table 4.15, it shows that all variables correlate significantly with organizational commitment. The strongest linear relationship was found to exist between organizational commitment and organizational working environment $(r=0.76, p=0.01)$. The correlation coefficient of .76 shows a positive direction and a high strength. The second highest is found between organizational commitment and organizational leadership $(r=0.73, p=0.01)$. The correlation coefficient of .73 shows a positive linear relationship direction and the strength was high. The third highest was between organizational commitment and communication $(r=0.67, p=0.01)$ with a positive direction and a high strength too. In addition, person-organizational fit indicated a significant relationship ( $r=0.66, p=0.01)$ including training and career development $(r=0.65, p=0.01)$ and remuneration and recognition $(r=0.63, p=0.01)$ which show a positive direction and a moderate strength. Finally, there is a significant relationship between organizational commitment and challenging employment assignment $(r=0.51, p=0.01)$ which shows a positive direction and a moderate strength. 
INTERNATIONAL JOURNAL OF ACADEMIC RESEARCH IN BUSINESS AND SOCIAL SCIENCES Vol. 8, No. 7, July 2018, E-ISSN: 2222-6990 @ 2018 HRMARS

The scenario in Uni A shows that organizational work environment is the highest correlation with organizational commitment followed by leadership, communication with high strength and personorganization fit correlates with moderate strength. These findings are relevant with previous research findings that confirmed how organizational work environment act as an important human resource practice in retaining talent. Furthermore, non-monetary factors such as physical working condition, harmonious workplace, spirit of cooperation, work life balance, work safety, 'management and staff get along together' and employee welfare also do play as important organizational factors in retaining Uni A's talents.

Table 4.15: Correlation between HRP Variables and Organizational Commitment $(\mathrm{N}=282)$

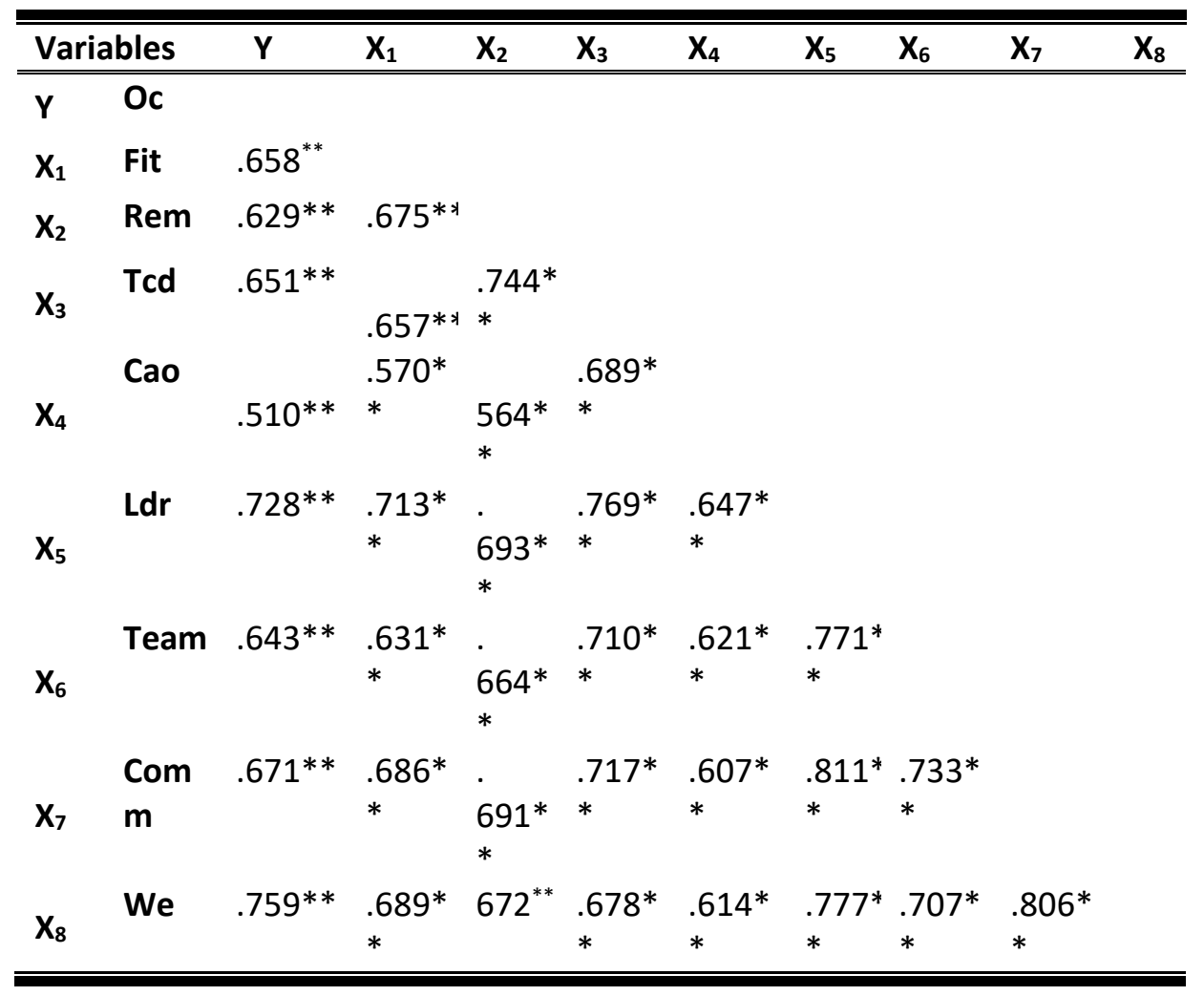

These factors are important to ensure talent intention to stay in Uni A and significantly increase their organizational commitment. Talent would leave for a better work place or working condition due to lack of good organizational work environment, (Perry-Smith \& Blum, 2000). Nowadays, the competition among the local universities and private universities in Malaysia to hire the talented staff, making it crucial to manage organizational commitment and intent to stay in order to retain them. Ignoring this relationship will be a risk to talent retention management and affecting university's function and performance (Vijaimadhavan \& Raju M.Com, 2013; Akintayo, 2012; Chandrasekar, 2011; Beham \& Drobnic, 2010). The diversity of talents in terms of age gap, gender, and type of occupation demands not only a highly effective leader but a change in managing work process through promoting team work job basis, and enhancing the work life balance among talents and making them to want to stay longer and committed to Uni A. A harmonious workplace and work life balance will increase talent intent to stay and commitment as well as job satisfaction. 
Organizational leadership shows a positive significant relationship with talent retention in Uni A. This finding is relevant with previous study among managers in U.S. which highlighted that effective leader and leadership practices that support high performing employee will contribute to high retention among talents (Hoffman et al., 2013). This study also confirm earlier research finding that leadership which provides direction will enhance retention (Leimbach, 2006), and increase job satisfaction and commitment (Aimo-Metcalfe \& Alban-Metcalfe, 2001; Podsakoff, MacKenzie \& Bommer,1996).

In addition, Uni A's talent demanded a clear and openness in providing and communicating universities vision, mission and action plan. An effort towards providing a clear data communication structure towards responding to staff complaints and ideas will contribute to enhance job satisfaction and staf intent to stay (Muhammad et al., 2012; Sh.Kandelousi \& Kim Seong, 2011; Gilley, Gilley, \& McMillan, 2009; Carter, Ulrich, \& Goldsmiths, 2005). Communication emerged as an essential process in talent retention.

Talent in Uni A also appreciate the fact that matching their values with Uni A's values are important in talent retention. Person-organization fit is considered in the context of personnel selection and can be based on the congruity between personal and organization beliefs (Netmeyer, Boles, McKee, \& McMurrian, 1997). In addition, person-organization fit in terms of work values and honesty will increase in work outcome, and retention (Swaney, Alllen, Casillas, Hanson, \& Robbins, 2012; Greguras \& Diefendorff, 2009).

In Uni A, the other human resource factors such as remuneration, training and career development and challenging job assignment and opportunities should not be lacking behind. Remuneration package offered by the Government of Malaysia and the implementation of other non-monetary benefits in the form of recognition and rewards fulfilled the expectation of the talent and increased their job satisfaction (Hansen, Smith, \& Hansen, 2002; Parker \& Wright, 2000) and influence them to stay longer in Uni A. Employees tend to remain with the organization when they feel their capabilities, effort, and performance contributions are recognized and appreciated (Davies R. , 2001). A rewardretention link supported the notion that a broad and well-implemented rewards and recognition program assist in talent retention management (Mercer, 2003). In addition, the implementation of a structured training and career development and providing a challenging work assignment and opportunities contribute to the increase in knowledge and skill of the talent. A concerted effort between the human resource office and staff association is needed to initiate a better pay and recognition package that matches talent contribution to the university. The economic factors such as inflation and higher cost of living demanding the pays and recognition package that are reliable and affordable for a living. The new way of thinking and doing things in the fourth industrial revolution demand an innovative training for career development among talent to ensure that they are equipped with the skills and knowledge which are suitable and current be it in teaching and learning, research, innovation and commercialization. This initiave may possibly avoid talents from leaving Uni A and looking for greener pastures and opportunities elsewhere. Hence, objective three of the study highlighted that there is a significant relationship between human resource practices and talent retention among the professional and management staff in Uni A. 
INTERNATIONAL JOURNAL OF ACADEMIC RESEARCH IN BUSINESS AND SOCIAL SCIENCES

Vol. 8, No. 7, July 2018, E-ISSN: 2222-6990 (C) 2018 HRMARS

The Influence of Human Resource Practices on Talent Retention among Professional and Management Staff in Uni A

\section{Intent to Stay Regression Model}

The ANOVA shown in Table 4.16 table indicates that all eight predictor variables were found to be significant in explaining intent to stay $F(8,283)=15.00, p=.0001$. The F-statistics $(F=15.00)$ is very large and the corresponding $p$-value is highly significant $(p=0.01)$ or lower than the alpha-value of 0.05 . This indicates that the slope of the estimated linear regression model line is not equal to zero confirming that there is linear relationship between intent to stay and the eight predictor variables. Therefore, this analysis proposes the simple linear regression model is as the following equation:

$Y_{1}=B_{0}+B_{1} X_{1}+B_{2} X_{2}+B_{3} X_{3}+B_{4} X_{4}+B_{5} X_{5}+B_{6} X_{6}+B_{7} X_{7}+B_{8} X_{8}$

Table 4.16: ANOVA for Intent to stay

\begin{tabular}{|c|c|c|c|c|c|c|}
\hline \multirow[b]{2}{*}{ I } & & \multicolumn{2}{|c|}{ Sum of } & \multicolumn{3}{|l|}{ Mean } \\
\hline & & Squares & $d f$ & Square & $\mathrm{F}$ & Sig. \\
\hline \multirow[t]{3}{*}{1} & $\begin{array}{l}\text { Regressi } \\
\text { on }\end{array}$ & 155.35 & 8 & 19.42 & 15.00 & $.000^{\mathrm{a}}$ \\
\hline & Residual & 366.32 & 282 & 1.30 & & \\
\hline & Total & 521.67 & 282 & & & \\
\hline
\end{tabular}

a. Predictors: (Constant), MWe, MCao, MRem, MFit, MTeam, MTcd, MComm, MLdr

b. Dependent Variable: Mits

However, as depicted in Table 4.17, only organizational working environment obtained the largest beta coefficient of 0.53 with the highest t-statistic of 4.86 and $p$ value is 0.01 which is less than alpha value of 0.05 . This means that this variable makes the strongest unique contribution in explaining the dependent variable of intent to stay. It suggests that one standard deviation increase in organizational working environment is followed by 0.53 standard deviation increase in intent to stay as in the following equation:

$Y_{1}=1.91-0.02 X_{1}+0.15 X_{2}+0.09 X_{3}+0.06 X_{4}+0.07 X_{5}+0.11 X_{6}-0.12 X_{7}+0.53 X_{8}$ 
INTERNATIONAL JOURNAL OF ACADEMIC RESEARCH IN BUSINESS AND SOCIAL SCIENCES

Vol. 8, No. 7, July 2018, E-ISSN: 2222-6990 @ 2018 HRMARS

Table 4.17: Regression Result for Intention to Stay

\begin{tabular}{|c|c|c|c|c|c|}
\hline $\begin{array}{l}\text { Model } 1 \\
\text { Intent } \\
\text { stay }\end{array}$ & $\begin{array}{l}\text { Unstandardiz } \\
\text { to ed } \\
\text { Beta }\end{array}$ & $\begin{array}{l}\text { Std. } \\
\text { Erro } \\
r\end{array}$ & $\begin{array}{l}\text { Standardize } \\
\text { d Beta }\end{array}$ & $\mathrm{t}$ & Sig. \\
\hline Fit & -0.02 & $\begin{array}{l}0.0 \\
4\end{array}$ & 0.03 & -0.24 & 0.81 \\
\hline Rem & 0.15 & $\begin{array}{l}0.0 \\
5\end{array}$ & 0.16 & 1.49 & 0.14 \\
\hline Tcd & 0.09 & $\begin{array}{l}0.0 \\
5\end{array}$ & 0.11 & 0.88 & 0.38 \\
\hline Cao & 0.06 & $\begin{array}{l}0.0 \\
5\end{array}$ & -0.06 & 0.59 & 0.56 \\
\hline Ldr & 0.07 & $\begin{array}{l}0.0 \\
5\end{array}$ & 0.09 & 0.68 & 0.50 \\
\hline Team & 0.11 & $\begin{array}{l}0.0 \\
5\end{array}$ & 0.12 & 1.07 & 0.28 \\
\hline Comm & -0.12 & $\begin{array}{l}0.0 \\
6\end{array}$ & -0.14 & -1.09 & 0.28 \\
\hline We & 0.53 & $\begin{array}{l}0.0 \\
6\end{array}$ & 0.55 & 4.86 & 0.00 \\
\hline
\end{tabular}

Dependent Variable: ITS, $R=.55, R^{2}=.30$

The regression analysis results confirmed how intention to stay model fits with the data as in the following:

$$
\begin{aligned}
& Y_{1}=B_{0}+B_{8} X_{8} \\
& Y_{1}=1.91+0.53 X_{8}
\end{aligned}
$$

In addition, the R-squared of 0.30 indicated that the eight predictor variables explain about $30 \%$ of the variance in the intent to stay. This dictates that from the eight HRP variables chosen for this study, only $30 \%$ contributes towards intent to stay which means that there are other factors should be measured to examine the influence of HRP and intent to stay. Again, finding shows that organizational work environment (WE) is the only dominant HRP that influence Uni A talent to stay longer in the university.

A well implemented human resource practices is crucial in order to ensure talent to stay longer (Kehoe \& Wright, 2013) and thus contribute towards fulfilling Uni A's mission and vision. The lack of concern on talent retention among HR managers and top management in Uni A will lead to a huge loss not only in monetary term but also knowledge. Therefore, it is important for Uni A to implement a strategic human resource practice that encourage talented staff to stay and remain in Uni A. 
INTERNATIONAL JOURNAL OF ACADEMIC RESEARCH IN BUSINESS AND SOCIAL SCIENCES

Vol. 8, No. 7, July 2018, E-ISSN: 2222-6990 @ 2018 HRMARS

\section{Organizational Commitment Regression Model}

In order to determine the extent of the research data fit, the enter method was used. According to ANOVA Table 4.18 , all 8 predictor variables were found to be significant in explaining organizational commitment $F(8,284)=67.47, p=.0001$. F-statistics $(F=67.47)$ is very large and the corresponding $p$-value is highly significant $(p=0.01)$ or lower than the alpha-value of 0.05 . This indicates that the slope of the estimated linear regression model line is not equal to zero confirming that there is linear relationship between organizational commitment and the eight predictor variables. Therefore, this analysis proposes the simple linear regression for organizational commitment model to be as in the following equation:

$Y_{1}=B_{0}+B_{1} X_{1}+B_{2} X_{2}+B_{3} X_{3}+B_{4} X_{4}+B_{5} X_{5}+B_{6} X_{6}+B_{7} X_{7}+B_{8} X_{8}$

Table 4.18: ANOVA for Organizational Commitment

\begin{tabular}{lllllll}
\hline \multicolumn{2}{l}{ Model } & \multicolumn{2}{l}{ Sum } & of & \multicolumn{2}{l}{ Mean } \\
\hline 1 & Squares & df & Square & F & Sig. \\
\hline & Regressio & 185.58 & 8 & 23.20 & 67.47 & $.000^{\mathrm{a}}$ \\
& $\mathrm{n}$ & & & & & \\
& Residual & 97.65 & 282 & .34 & & \\
& Total & 283.22 & 282 & & & \\
\hline
\end{tabular}

a. Predictors: (Constant), MWe, MCao, MRem, MFit, MTeam, MTcd, MComm, MLdr

b. Dependent Variable: MOc

As depicted in Table 4.19, the largest beta coefficient is 0.38 is for organizational working environment and this corresponds with the highest t-statistic of 6.73 and $p$ value is 0.00 which is less than alpha value of 0.05 . This means that this variable makes the strongest unique contribution to explain the dependent variables of organizational commitment, when the variance explained by all other predictor variables in the model is controlled. It suggests that one standard deviation increase in organizational working environment is followed by 0.38 standard deviation increase in intent to stay. The second largest beta coefficient is organizational leadership $(B=0.16)$ with corresponding tstatistic of 3.12 and the $p$ value is 0.00 which is less than alpha value of 0.05 . This is followed by organizational fit $(B=0.10)$ and corresponding t-statistics is 2.38 and the $p$ value is 0.02 which is less than alpha value of 0.05 . Therefore, organizational working environment, organizational leadership and organizational fit were identified to be the best predictors for organizational commitment and summarized as in the following equation:

$Y_{1}=1.84+0.10 X_{1}+0.05 X_{2}+0.09 X_{3}-0.09 X_{4}+0.16 X_{5}+0.03 X_{6}-0.04 X_{7}+0.38 X_{8}$ 
INTERNATIONAL JOURNAL OF ACADEMIC RESEARCH IN BUSINESS AND SOCIAL SCIENCES Vol. 8, No. 7, July 2018, E-ISSN: 2222-6990 @ 2018 HRMARS

Table 4.19: Regression Result for Organizational Commitment

\begin{tabular}{llllll}
\hline Model & $\begin{array}{l}\text { Unstandardiz } \\
\text { ed } \\
\text { Beta }\end{array}$ & $\begin{array}{l}\text { Std. } \\
\text { Error }\end{array}$ & $\begin{array}{l}\text { Standardiz } \\
\text { ed Beta }\end{array}$ & $t$ & Sig. \\
\hline Fit & 0.10 & 0.04 & 0.13 & 2.38 & 0.02 \\
Rem & 0.05 & 0.05 & 0.06 & 0.97 & 0.33 \\
Tcd & 0.09 & 0.05 & 0.11 & 1.72 & 0.07 \\
Cao & -0.09 & 0.05 & -0.09 & 1.71 & 0.09 \\
Ldr & 0.16 & 0.05 & 0.23 & 3.12 & 0.00 \\
Team & 0.03 & 0.05 & 0.04 & 0.65 & 0.52 \\
Comm & -0.04 & 0.06 & -0.05 & 0.68 & 0.50 \\
We & 0.38 & 0.06 & 0.45 & 6.73 & 0.00 \\
\hline
\end{tabular}

Dependent Variable: $O C, R=0.81 R^{2}=0.66$

Therefore, the estimated organizational commitment model fit the data as the following:

$$
\begin{aligned}
& Y_{2}=B_{0}+B_{1} X_{1}+B_{5} X_{5}+B_{8} X_{8} \\
& Y_{2}=1.84+0.10 X_{1}+0.16 X_{5}+0.38 X_{8}
\end{aligned}
$$

In addition, the R-squared of 0.66 indicates that the eight predictor variables explain about $66 \%$ of the variance in the organizational commitment. This result shows that from the eight HRP variables chosen for this study, about $66 \%$ contributes towards organizational commitment which means that there are other factors to be measured to examine the influence of HRP and organizational commitment. The result also shows that organizational work environment is the dominant factor to influence organizational commitment followed with organizational leadership and personorganization fit.

Therefore, the finding shows that Uni A work environment is an important HRP factor in order to increase organizational commitment among the Uni A talent. Investing on money and effort to maintain and strengthen its organizational environment should be a priority. The ability to balance between work life and family life will enable talent to not only perform better in their role or job demands, but also to flourish, be creative and innovative in their careers. In Uni A, work environment that encourages greater cohesion among organization members and knowledge sharing and commitment to common goal will retain their talent to stay longer and increase organizational commitment. This study confirmed that enrichment and synergies from non-work roles can improve performance at work. This is important in Uni A especially their talent consists of new generation of $X$ and $Y$ in which they demand for a flexible job arrangement, and a massive use of technology in performing their functions.

Other dominant factors that influence organizational commitment are organizational leadership and person-organization fit. Leadership is important due to providing clear direction of the university in achieving competitive advantage and this is relevant with previous study that highlighted the importance role of organizational leadership in achieving organizational performance and retention (Kane, 2000; Delery, 1996; Huselid, 1995; Pfeffer, 1994). This finding is also similar with the 
INTERNATIONAL JOURNAL OF ACADEMIC RESEARCH IN BUSINESS AND SOCIAL SCIENCES

Vol. 8, No. 7, July 2018, E-ISSN: 2222-6990 @ 2018 HRMARS

proposition that a high-involvement work practices enhances employee retention (Paauwe, 2009; Koch \& McGrath, 1996). In retaining talent through organizational commitment, the model shows the importance of fit between person and organization value among talent in Uni $A$. This finding is relevant with previous study that reveal how personnel selection can be based on the congruity between personal and organization belief (Netmeyer et al., 1997). Person-organization fit in terms of work values and honesty will increase work outcome and retention (Swaney et al., 2012; Greguras \& Diefendorff, 2009).

Therefore, the finding of objective four in the study shows that organizational work environment is the dominant factor that influences talent in Uni A to remain in the university followed by organizational leadership and person-organization fit. The finding also shows that organizational commitment is better in explaining retention among Uni A talent as compared to intent to stay.

\section{Recommendation}

Uni A needs to develop its talent retention management strategies that consider work environment as its major focus. It needs to strengthen its HRD roles that contribute towards developing effective leaders and managers and implementing person-organization fit that embraces good values as stated in the following sections;

\section{Working Environment Strategy}

Working environment strategies address three fundamental aspects of the workplace: the ethics and values; the policies that interpret those values into daily actions, and the physical environment in which talent work. The overall goal is to make Uni A a place where talents want to come to work and to stay longer at the campus. Specifically in Uni A, it is recommended that the university promotes a culture of openness and shared information, a campus with and open apolitical culture and relatively autonomous. In addition to that, the introduction of a flexi-time and job-sharing policies as a way to retain talent and gain reputation as family-friendly environment could attract more future potential talent to work in the university. Additional initiatives can include providing more childcare and/or eldercare centers, and to offer some funding for fitness club membership among talent.

In addition to that, university should assess talents' reason to work. This activity will persuade talent to reinforce their reason to work for the universities and this will let the universities to gain better insights of what attracts talented employee to work in the universities. Finally, university should also assess talents' opinion on the improvement initiatives. This will encourage good ideas, not only for improving conditions for the talents' benefit but also for all facets of university work environment. This can be done by undertaking survey on ways and means to transform Uni $A$ into a likeable organization.

\section{Human Resource Development (HRD) Strategy}

There is a need to relook and redesign the programs and activities that would positively enhance work environment and commitment of the Uni A staff. University should design and develop effective HRD program to develop talent and let them grow and become innovative. It involves strengthening the leadership program and other development activities that contributes to talents' growth as the following; 
INTERNATIONAL JOURNAL OF ACADEMIC RESEARCH IN BUSINESS AND SOCIAL SCIENCES Vol. 8, No. 7, July 2018, E-ISSN: 2222-6990 @ 2018 HRMARS

\section{Leadership Program}

It is suggested that the university should execute more leadership and teamwork programs for the staff. This is important for the talent to have the knowledge, training and sensitivity to work effectively, in order to create the bonding and finally to retain them. HRD roles is to venture to the future trends of workforce in higher education to ensure that the staff are up to date with their surroundings. Besides that, leadership and person-organization fit factors should be considered by the HR as an important aspect in crafting their leadership program. Strengthening the role of HRD to develop and design value-based leadership and teamwork program may encourage talent to understand, internalize and embrace Uni A's organizational core values. Promoting leadership mentoring and people management skills will prepare talent to excel in their role as leaders of the university.

\section{Training and Growth Program}

Universities need to nurture personal and professional growth among their talent with new knowledge and skills. Talented employees need an organized and structured training program that meets talents' different needs making them feel closer to Uni A. Personal and professional growth program can be promoted by increasing the number of in-house training and development, seminars and workshops, funding for continuing professional education as well as career development support.

Finally, top level management and HR department officers can be trained as professional human resource managers in nurturing talent of the university. A successful HR manager must be aware of their strengths and weaknesses and have the ability to listen, respect, and understand their employees' concerns.

\section{Person-Organization Fit Strategies}

Uni A is facing a dynamic and changing environment which requires talents whose values fit with their organizational values, goals and cultures. As for the talents, the compatibility between them and organization is an important factor that determines whether they would be willing to stay longer with and remain committed to the organization. Therefore, Uni A should implement the personorganization fit strategies to ensure that both organization and talents gain the objectives of fit. It is suggested that the university to adopt the strategies even during the recruitment and selection processes. It is recommended that Uni A should develop or identify a standardized common metric to assess applicant's fit in terms of value, honesty, clear university's goals and directions with much consideration given toward assessing the candidate's future fit with the university. The second strategy is for the university to provide a clear and structured communication plan that would share the university's values, goals, direction and achievement to talents in the university systematically. The third strategy is by creating socialization platform between university's management and talents to find high degree of FIT. Socialization platform can be in the form of scheduled meeting with talents, get- together events such as sport day, family day or dinners with talents. Finally, implementing a clear career development planning strategies will also enhance the person-organization fit. 


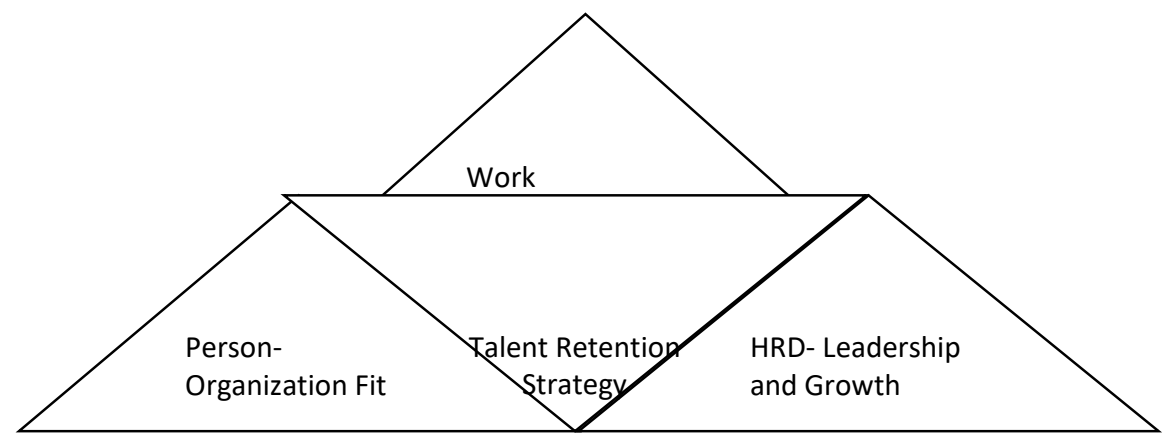

Figure 5. 1: Retention Management Strategy

It is apparent that career development plan can assist talents to measure their abilities to converge their personal goals as well as their organizational goals. Only organizations that give priorities to career development will sustain and remain relevant to cope with future challenges and demands.

\section{Conclusion}

The study confirmed that there is a significant relationship between human resource practices and retaining talent. Organizational factors shows a significant relationship with intent to stay as compared to human resource factors. It can be concluded that talents in this study are willing to remain longer and are committed to the organization due to the positive organizational work environment surrounding their professional and personal lives.

\section{References}

Abd. Aziz, M., \& Abdullah, D. (2014). Malaysia: Becoming an education hub to serve national development. In J.Knights, International Education Hub: Student, Talent, KnowledgeInnovation Model. New York: Springer. doi:10.1007/978-94-007-7025-6-7

Abdullah, R., Zain, R., Musa, M., Khalid, K., Mohd Tajudin, M., Radzuan, N., Sekharan Nair, G. (2012). The effects of teamwork towards jobs satisfaction in hotel industry in Klang. International Journal of Business and Behavioral Sciences, 2(3), 8-19. Retrieved 4 20, 2014, from http://cprenet.com/ uploads/ archive/ IJBBS 12-1113

Akintayo, D. (2012). Working environment, workers' morale and perceived productivity in industrial organizations in Nigeria. Education Research Journal, 2(3), 87-93. doi:ISSN: 2026-6332 (C2012.

Alimo-Metcalfe, B., \& Alban-Metcalfe, R. (2001). The development of a new transformational leadership questionnaire. Journal of Occupational and Organizational Psychology, 74, 1-7.

Armstrong, M. (2003). A handbook of human resource management practice. London UK: Kogan Page $\begin{array}{lllll}\text { Publisher. } & \text { Retrieved } & \text { April } & 17, & \text { from }\end{array}$ http://books.google.com.my/books?hl=en\&lr=\&id=2AGbuhlTXVOC\&oi=fnd\&pg=PR17\&dq=h uman+resource+practice+concept\&ots=ZmKq4MIOD2\&sig=Xi9aesxGNdSocNAStyaUTfEAlis\# $\mathrm{v}=$ onepage \&q=human\%20resource\%20practice\%20concept\&f=false.

Arokiasamy, L., Ismail, M., Ahmad, A., \& Othman, J. (2011). Determinants of career advancement of academics in private institutions of higher learning in Malaysia. 10th International Conference of the Academy of HRD (Asia Chapter): Human Resource Development in Asia : Capitalizing on 
INTERNATIONAL JOURNAL OF ACADEMIC RESEARCH IN BUSINESS AND SOCIAL SCIENCES

Vol. 8, No. 7, July 2018, E-ISSN: 2222-6990 @ 2018 HRMARS

Human Expertise for Greater Innovation and Creativity, 1-11. Kuala Lumpur: Faculty of Educational Studies UPM.

Arthur, J. (1994). Effects of human resource systems on manufacturing performance and turnover. Academy of Management Journal, 37(3), 670-687.

Barney, J, (1991). Firm resources and sustained competitive advantage. Journal of Management, 17(1), 99-120

Batt, R., \& Colvin, A. J. (2011). An employment system approach to turnover: human resources practices, quits, dismissals, and performance. Academy of Management Journals , 54 (4), 695-711.

Bass, B.M. \& Avolio, B.J. (1990). Re-examining the components of transformational and transactional leadership using the multi-factor leadership questionnaire. Joumal of Occupational and Organisational Psychology, 72, 441-462

Bassi, L., \& Van Buren, M. (1999). Sharpening the leading edge. Training and Development, 53 (1), 23 32.

Becker, B., \& Gerhart, B. (1996). The impact of human resource management on organizational performance. Academy of Management Journal, 39, 779-801.

Beham, B., \& Drobnic, S. (2010). "Satisfaction with work-family balance among German office workers. Journal of Managerial Psychology, 25(6), 669-689. doi:10.1108/02683941011056987.

Broadfoot, L.E., \& Ashkanasy, N.M. (1994). A survey of organizational culture measurement instruments. Paper presented at the Annual General Meeting of Australian Social Psychologists, Cairns, Queensland, Australia.

Byrman, A. (1992). Charisma and leadership in organization. Newbury CA: Sage Publications.

Cammann,C., Fichman, M., Jenkins, D., \& Klesh, J. (1979). The Michigan organizational assessment questionnaire. Unpublished manuscript, University of Michigan, Ann Arbor, Michigan.

Capelli, P. (1995). Is the skill gap really about attitudes? California Management Review, 37(4), 108125.

Carette, B., Anseel, F., \& Lievens, F. (2012). Does career timing of challenging job assignments influence the relationship with in-role job performance? Journal of Vocational Behavior, 6167. doi:http://dx.doi.org/10.1016/j.jvb.2013.03.001

Carter, L., Ulrich, D., \& Goldsmiths, M. (2005). Best practices in leadership development and organization change. San Francisco: Pfeiffer A Wiley Imprint. Retrieved April 20, 2014, from https://lib.nu.edu.sa/uploads/m1/10.

Chandrasekar, K. (2011). Workplace environment and its impact on organizational performance in public sector organization. International Journal of Enterprise Computing and Business Systems (online), 1(1). Retrieved from http://www.ijecbs.com

Chung, J.C., \& Jing, W. H. (2009). Strategic human resource practices and innovation performance the mediating role of knowledge management capacity. Journal of Business Research, 62, 104114.

Clarke, K. (2001, March). What businesses are doing to attract and retain employee becoming an employer of choice. Employee Benefits Journal, 3, 34-37.

Cook, J.D., Hepworth, S.J., Wall, T.D., \& Warr, P.B. (Eds). (1981). Experience of Work: A compendium and review of 249 measures and their use. New York: Academic Press. 
INTERNATIONAL JOURNAL OF ACADEMIC RESEARCH IN BUSINESS AND SOCIAL SCIENCES

Vol. 8, No. 7, July 2018, E-ISSN: 2222-6990 @ 2018 HRMARS

Darling Hammond, L. (2010). Recruiting and Retaining Teachers: Turning Around the Race to the Bottom in High-Need Schools. Journal of Curriculum and Instruction, 4(1), 16-32.

Davies, B., \& Davies, B. J. (2010). Talent management in academies. International Journal of Educational Management, 24(5), 418-426.

Davies, R. (2001, April 19). How to boost staff retention. People Management, 7(18), 54-56.

De Cieri, H., \& Kramar, R. (2008). Human resource management In Australia: strategy, people, performance (3rd. ed.). Sydney: McGraw Hill Australia Pty. Limited.

Delery, J., \& Doty, D. (1996). Theoretical frameworks in strategic human resource management: universalistic, contingency and configurational perspectives. Academy of Management Journal, 39, 802-835.

Demerouti, E., Derks, D., Brummelhuis, L., \& Arnold B., B. (2014). New ways of working: impact of working conditions, work-family balance, and well-being. In C. Korunka, \& P. Hoonakker, The impact of ICT on quality of working life. Netherlands: Springer Netherlands. doi:10.1007/97894-017-8854-0_8

Edwards, J. (1991). Person-Job Fit: A conceptual integration, literature review, and methodological critique. In C. Cooper, \& I. Robertson, International Review of Industrial and Organizational Psychology (pp. 283-357). John Wiley and Son Ltd.

Fatima, H. (2011). Does employee retention affect organizational competence. The International Institute for Science, Technology and Education (IISTE), 1(1), 24-39. Retrieved April 19, 2014, from www.iiste.org.

Ferguson, W. (1990). Creative compensation: Keeping employees on board. Journal of Property Management, 55(3), 12-16.

Frazis, H., Gittleman, M., Horrigan, M., \& Joyce, M. (1998). Results from 1995 survey of employerprovided training. Monthly Labor Review, 121(6), 3-14.

Furnham, A. (2002). Work in 2020 Prognostications about the world of work: 20 years into the millennium. Journal of Managerial Psychology, 15(3), 242-250.

Gilley, A., Gilley, J., \& McMillan, H. (2009). Organizational change: motivation,communication, and leadership effectiveness. Performance Improvement Quarterly, 21(4), 75-94. doi:DOI: 10.1002/piq.20039

Greguras, G., \& Diefendorff, J. (2009). Contextualizing emotional display rules: taking a closer look at targets, discrete emotions and behavioral responses. Journal of Management, 35, 880-898.

Grobler, P., \& Diedericks, H. (2009). Talent management: An empirical study of selected South African hotels groups. Southern African Business review, 13 (3), 1-27.

Hackman, J. R., \& Oldham, G. R. (1975). Development of the job diagnostic survey. Journal of Applied Psychology, 60, 159-170.

Hansen, F., Smith, M., \& Hansen, R. (2002). Rewards and recognition in employee motivation. Compensation Benefits Review, 34(5), 64-75. doi:DOI: 0.1177/0886368702034005010

Hartog D.N., Van Muiijen, J.J., \& Koopmen, P.L. (1997). Transactional versus transformational leadership: An analysis of the MLQ. Journal of Occupational and Organizational Psychology, 70, 19-34

Hashim, M. S. (2010). UKM measures its quality through KPIs benchmarked with international good practice. Bangi: UKM News Portal. 
INTERNATIONAL JOURNAL OF ACADEMIC RESEARCH IN BUSINESS AND SOCIAL SCIENCES

Vol. 8, No. 7, July 2018, E-ISSN: 2222-6990 @ 2018 HRMARS

Hart, Z., Miller, V., \& Johnson, J. (2003). Socialization, resocialization, and communication relationships in the context of an organizational change. Communication studies, 54(4), 483496.

Hausknecht, J. P., \& Trevor, C. O. (2011). Collective turnover at the group, unit, and organizational levels: evidence, issues, and implications. Journal of Management, 37 (1), 352-388.

Hazelkorn, E. (2013). How rankings are reshaping higher education . in V. M. Climent, How rankings are reshaping higher education (1-8). Dublin Institute of Technology: Ed Technos.

Hoffman, B., Strang, S., Kuhnet, K., Campbell, W., Kennedy, C., \& LoPilato, A. (2013). Leader narcissism and ethical context: effects on ethical leadership and leader effectiveness. Journal of Leadership \& Organizational Studies, 20, 25-37. doi:Published online before print November 27, 2012, doi: 10.1177/1548051812465891

Holland, P., Sheehan, C., \& De Cieri, H. (2007). Attracting and retaining talent: Exploring human resource development trends in Australia. Human Resource Development International, 10(3), 247-262.

Hughes, J. C., \& Rog, E. (2008). Talent management: a strategy for improving employee recruitment, retention and engagement within hospitality organizations. International Journal of Contemporary Hospitality Management , 20 (7), 743-757

Huselid, M. A. (1995). The impact of human resource management practices on turnover, productivity, and corporate financial performance. Academy of Management Journal , 38 (3), 635-672.

Iles, P., Chuai, X., \& Preece, D. (2010). Talent management and HRM in multinational companies in Beijing: definitions, differences and drivers. Journal of World Business, 45(2), 179-189.

Jackson, P. R., Wall, T. D., Martin, R., \& Davids, K. (1993). New measures of job control, cognitive demand, and production responsibility. Journal of Applied Psychology, 78, 753-762.

Jackson, S., \& Schuler, R. (1996). Understanding human resource management in the context of organizations and their environment (46). (J. D. J.T. Spence, Ed.) Palo Alto, CA: Annual Reviews.

Kalisch, B., Lee, H., \& Rochman, M. (2010). Nursing staff teamwork and job satisfaction. Journal of Nursing Management, 18(8), 938-947. doi: 10.1111/j.1365-2834.2010.01153.x

Kane, R. (2000). Downsizing, TQM, reengineering, learning organizations and HRM Strategy. Asia Pacific Journal of Management , 38 (1), 26-48.

Kaye, B., \& Jordan-Evans, S. (2014). Love 'em or lose 'em: Getting good people to stay. San Francisco,California: Berrett-Koehler Publishers.

Kehoe, R., \& Wright, P. (2010). The impact of high performance human resource practices on employees' attitude and behaviors. Journal of Management, 36(X), 1-25.

Kehoe, R., \& Wright, P. (2013). The impact of high-performance human resource practices on employees' attitudes and behaviors. Journal of Management, 39(2), 366-391. doi:10.1177/0149206310365901

Koch, M., \& McGrath, R. (1996). Improving labour productivity: Human resource management policies do matter. Strategic Management Journal, 17, 335-354.

Kwenin, D. O., Muathe, S., \& Nzulwa, R. (2013). The Influence of Employee Rewards, Human Resource Policies and Job Satisfaction on the Retention of Employees in Vodafone Ghana Limited. European Journal of Business and Management ,5(12),13-20. www.iiste.org ISSN 2222-1905 (Paper) ISSN 2222-2839 (Online) 
INTERNATIONAL JOURNAL OF ACADEMIC RESEARCH IN BUSINESS AND SOCIAL SCIENCES

Vol. 8, No. 7, July 2018, E-ISSN: 2222-6990 @ 2018 HRMARS

Lado, A., \& Wilson, M.C. (1994). Human resource systems and sustained competitive advantage: a competency-based perspective. Academy of Management Review,19(4), 699-727.

Lee, F., \& Lee, F. (2007). The relationship between HRM practices, leadership style, competitive strategy and business performance in Taiwanese steel industry. Asia Pacific Management Conference. Melbourne, Australia.

Leimbach, M. (2006). Redefining employee satisfaction: business performance, employee fulfillment, and leadership practices. Edina: Wilson Learning Worldwide Inc. Retrieved April 20, 2014, from http://www.wilsonlearning.com/images/uploads/pdf/employee_satisfaction_en.

Mendez, F., \& Stander, M. (2011). Positive organization.The role of leader behaviour in work engagement and retention. South African Journal of Induetrial Psychology, 1-13. doi:doi: 10.4102/sajip.v37i1.900

Mercer. (2003). Mercer study raises red flags for employer pay and benefit plans (findings of the 2002 People at work survey). Human Resource Department Management Report.

Meyer, J., \& Allen, J. (1997). Commitment in the the workplace: Theory, research, and application. Thousand Oaks: Sage Publications, Inc.

Mohan, T., \& Russell, B. (2010). Work organization, human resource practices and employee retention in Indian call centers. Asia Pacific Journal of Human Resources , 48 (3), 356-374.

Mowday, R., Porter, L., \& Steers, R. (1979). Employee-organizational linkages: The psychology of commitment, absenteeism, and turnover. New York: Academic Press.

Muhammad, A., Ur Rehman, K., Safwan, N., \& Asad, A. (2012). role of effective communication in retention and motivation of employees. International Conference on Arts, Behavioral Sciences and Economics Issues (ICABSEI'2012) (pp. 64-67). Phuket: ICABSEI'2012.

Nazir, T., Khan, S.-u.-R., Hussain Shah, S. F., \& Zaman, K. (2013). Impact of rewards and compensation on job satisfaction: Public and private universities of UK. Middle-East Journal of Scientific Research, 14(3), 394-403.

Netmeyer, R., Boles, J., McKee, D., \& McMurrian, R. (1997). An investigation into the antecedents of organizational citizenship behaviors in a personal selling context. Journal of Marketing, 61, 85-98.

Ng Chee Hong, E., Lam, Z., Kumar, R., Ramendran, C., \& Kadiresan, V. (2012). An effectiveness of human resource management practices on employee retention in institute of higher learning: - A regression analysis. International Journal of Business Research and Management (IJBRM), 3(2), 60-79. Retrieved 4 22, 2014

Noe, R. (1999). Employee training and development. New York: Irwin McGraw-Hill.

Noraani, M., Aminah, A., Jegak, U., \& Khairudin, I. (2010). Job Characteristics as Antecedents of Intention to Stay and Mediating Effects of Work Family Facilitation and Family Satisfaction among Single Mothers in Malaysia. International Journal of Business and Social Science, 1(3), 59-74.

Oakland, S., \& Oakland, J. (2001, Sept.). Current people management activities in world-class organizations. Total Quality Management, 12(6), 773-779.

Paauwe, J. (2009). HRM and performance: Achievements, methodological issues and prospects. Journal of Management Studies, 46(1), 129-142. doi:doi: 10.1111/j.1467-6486.2008.00809.x

Park, T.-Y., \& Shaw, J. (2013). Turnover rates and organizational performance: a meta-analysis. Journal of Applied Psychology, 98(2), 268 -309. doi: DOI: 10.1037/a00307 
INTERNATIONAL JOURNAL OF ACADEMIC RESEARCH IN BUSINESS AND SOCIAL SCIENCES

Vol. 8, No. 7, July 2018, E-ISSN: 2222-6990 @ 2018 HRMARS

Parker, S. R., \& Smith, M. A. Work and leisure. In R. Dubin (Ed.), (1976). Handbook of work organizations, and society. Chicago: Rand McNally.

Parker, O., \& Wright, L. (2000, Jan). Pay and employee commitment: the missing link. Ivey Business Journal, 65(3), 70-79.

Perry-Smith, J., \& Blum, T. (2000, Dec). Work family, human resource bundles and perceived organizational performance. Academy of Management Journal, 43(6), 1107-1112.

Pfeffer (1994). Competitive advantage through people. Boston MA: Harvard Business School Press.

Phillips, R. (1997). New measures for business. Measuring Business Excellence, 4-7.

Podsakoff, P., MacKenzie, S., \& Bommer, W. (1996). Transformational leader behaviors and substitutes for leadership as determinants of employee satisfaction, commitment, trust and organizational citizenship behaviors. Journal of Management, 22, 259-298.

Preenen, P. T., De Pater, I. E., Van Vianen, A. E., \& Keijzer, L. (2011). Managing voluntary turnover through challenging assignments. Group and Organization Management, 36(3), 308-344.

Puteh, F., Nor, F., \& Zulkifli, S. (2012). Determinants of employment mobility trend among Malaysian young talents. IEEE Symposium on Business, Engineering and Industrial Applications (ISBEIA), 2012 (102-107). Bandung: IEEE.

Risher, W., \& Stopper, W. (2002). Corporate sponsor forum. Human Resource Planning, 25(1), 5-10.

Seashore, S.E., Lawler, E.E., Mirvis, P., \& Cammann, C. (1982). Observing and measuring organizational change: A Guide to Field Practice. New York: Willey.

Shaw, J. D. (2011). Turnover rates and organizational performance: review, critique and research agenda. Organizational Psychology Review , 1 (3), 187-213.

Sh.Kandelousi, N., \& Kim Seong, N. (2011). Retention of generation Y's insurance agent: Mediating role of communication satisfaction. Global Journal of Management and Business Research, 11(6).

Siebert, W. S., \& Zubanov, N. (2009). Searching for the optimal level of employee turnover: A study of large U.K. retail organization. Academy of Management Journal , 52 (2), 294-313.

Sims, H. P., Szilagyi, A. D., \& Keller, R. T. (1976). The measurement of job characteristics. Academy of Management Journal, 19, 195-212.

Sinha, C., \& Sinha, R. (2012). Analysis of two organizations from heavy engineering industry. European Journal of Business and Management, 4(3), 145-162. Retrieved from file:///C:/Users/reg8/Downloads/1324-2984-1-SM.

Skirbekk, V. (2003). Age and individual productivity: A literature survey. Konrad-Zuse-Strasse 1 · D18057 Rostock: Max Planck Institute for Demographic Research. Retrieved 4 26, 2014, from http://www.demogr.mpg.de

Swaney, K., Alllen, J., Casillas, A., Hanson, M., \& Robbins, S. (2012). Interests, work values, and occupations predicting work outcomes with the workers' fit assessment. Journal of Career Assessment; November 2012 vol. 20 no. 4 359-374, 20(4), 359-374. doi:10.1177/1069072712448730

Tabachnick, G. B., \& Fidell, S. L. (2007). Using multivariate statistics (5th ed.). New York: Pearson Educational Inc.

Vagias, W.M. (2006). Likert-type scale response anchors. Clemson International Institute for Tourism \& Research Development, Department of Parks, Recreation and Tourism Management. Clemson University. 
INTERNATIONAL JOURNAL OF ACADEMIC RESEARCH IN BUSINESS AND SOCIAL SCIENCES

Vol. 8, No. 7, July 2018, E-ISSN: 2222-6990 @ 2018 HRMARS

Vijaimadhavan, P., \& Raju M.Com, D. (2013). An empirical study on relationship among quality of work life and its factors. Journal of Business and Management, 12(3), 20-28. doi:e-ISSN: 2278-487X, p-ISSN: 2319-7668

Wright, P. M., McMahan, G. C., \& McWilliams, A. (1994). Human resources and sustained competitive advantage: A resource-based perspective. The International Journal of Human Resource Management, 5(2), 301-326.

Youndt, M. (2000). Human resource configurations and value creation: the mediating role of intellectual capital. The 2000 Academy of Management Conference. Toronto, Ontario, Canada. 